\title{
Interdisciplinary, Cross-Cultural Research of Preschoolers' Linguistic Consciousness
}

\author{
Irina Markovina $^{1}$, Istvan Lenart ${ }^{1, *}$, and Orsolya Endrody ${ }^{2}$ \\ ${ }^{1}$ Sechenov University, Moscow, Russia \\ ${ }^{2}$ Eotvos Lorand University, Budapest, Hungary \\ *Corresponding author
}

Keywords: Early Childhood Education, Linguistic Consciousness, Cross-Cultural Studies.

\begin{abstract}
Results of a blended research are presented in this paper, which aim at cross-culturally comparing 4-5-year-old Russian and Hungarian preschoolers'verbal image of the world or linguistic consciousness. The interdisciplinary approach mingled the pedagogical approach with a psycholinguistic perspective, applying both the psycholinguistic theories of speech activity and linguistic consciousness, and the concept of childhood as a social construction. The prevailing methodology relied on the association experiment, complemented by the shoulder-to-shoulder method. Triangulation was ensured by the application of corpus linguistic methods for the analysis of the collected linguistic information. As a result of the study numerous universalistic (e.g. concept of family, perception of a child) as well as culture- and language-bound features (e.g. religious references) of Russian and Hungarian preschoolers' linguistic consciousness were identified. Numerous effects of globalization were revealed including brand names, info-communication tools, and cartoons.
\end{abstract}

\section{Introduction}

An effective tool of cross-cultural comparative investigation is the association experiment, developed by the Moscow School of Psycholinguistics [1]. In this paper, ten stimulus words were selected for the association experiment - friend, child, family, water, black, toy/game, devil, home/house, foreigner, and angel - aiming at comparing Hungarian and Russian 4-5-year-old pre-school children's verbal image of the world or linguistic consciousness [2]. The results obtained were analyzed applying both psycholinguistic and pedagogical approaches and theories, and were contrasted with Russian and Hungarian data from large corpora [3,4].

\section{Methods}

In order to compare Russian and Hungarian pre-school children's linguistic consciousness the aforementioned ten stimulus words were investigated with two respondent groups, comprising 
100-100 Hungarian and Russian pre-school children from the age group 4-5, respectively. Associations were collected and compiled into corpora for easier analysis.

The (psycho)linguistic approach was complemented with equal significance by the pedagogical perspective, initially by the selection of the stimulus words that well characterize the investigated age group, subsequently by applying the shoulder-to-shoulder method [5]. In consent with early childhood experts [6], children are considered in this research as 'actors' determining their own life.

\section{Results}

In this paper, cumulated results of the collected data from responses to the ten stimulus words are presented. Adjectives, nouns, and verbs are grouped separately and presented in order of frequency, displaying the top 10 reactions in each case, similarly to the 10 most frequent key single-words.

\subsection{Adjectives}

The 10 most frequent adjectives collected in the course of this research (Table 1.) display a high level of congruence in the Hungarian and Russian respondent groups. Preschoolers in both groups use, thus their linguistic consciousness heavily relies on adjectives of a generally positive value (good, kind, nice). Only one adjective with a negative denotation (bad) appeared in the top-10 results, in both groups. The small-big dichotomy appears in both respondent groups, while colors (white and black in both groups, red and blue in the Hungarian group) are also heavily present in preschoolers' linguistic consciousness.

Table 1. Ten Most Frequent Adjectives from Own Research and from Araneum corpora

\begin{tabular}{|c|c|c|c|c|c|}
\hline & \multicolumn{2}{|c|}{ Adjectives from own research } & & \multicolumn{2}{|c|}{ Adjectives from Araneum corpora } \\
\hline & Hungarian & Russian & & Hungarian & Russian \\
\hline 1. & jó (good) & маленький (small) & 1. & magyar (Hungarian) & белый (white) \\
\hline 2. & kedves (kind) & хороший (good) & 2. & nagy (big) & российской (Russian) \\
\hline 3. & fekete (black) & большой (big) & 3. & jó (good) & различных (different) \\
\hline 4. & kicsi (small) & белый (white) & 4. & új (new) & большой (big) \\
\hline 5. & nagy (big) & черный (black) & 5. & fontos (important) & новый (new) \\
\hline 6. & piros (red) & добрый (kind) & 6. & európai (European) & разных (various) \\
\hline 7. & fehér (white) & красивый (nice) & 7. & megfelelő (appropriate) & различные (divers) \\
\hline 8. & szép (nice) & настоящий (real) & 8. & kis (small) & основные (basic) \\
\hline 9. & kék (blue) & плохой (bad) & 9. & szép (nice) & данной (given) \\
\hline 10. & rossz (bad) & разный (different) & 10. & nemzeti (national) & настоящее (real) \\
\hline
\end{tabular}

Research findings are compared with the Hungarian (Araneum Hungaricum Maius) and Russian (Araneum Russicum Russicum Maius) corpora of the large-scale, comparable Araneum corpus family (Table 1.) - both corpora consisting of 800-900 million words. Besides discrepancies (i.e. the presence of adjectives referring to nations and geographic regions: Hungarian, Russian, European), noteworthy resemblance is identified including the small-big dichotomy, the presence of positive notions (good, nice, real) and of colors (white).

\subsection{Nouns}

The most remarkable lexical items of preschoolers' linguistic consciousness in both countries are persons surrounding them, including parents (mother in first and father in third place in both groups; see Table 2.) and friends. A key element of both Hungarian and Russian linguistic consciousness on the basis of the large-scale, country-wide Araneum corpus family is man/person (человек, етьеr). 
Table 2. Most Frequent Nouns from Own Research and from Araneum Corpora

\begin{tabular}{|c||ll||}
\hline & \multicolumn{1}{|c||}{ Nouns from own research } \\
\hline 1. & \multicolumn{1}{|c||}{ Hungarian } & \multicolumn{1}{c||}{ Russian } \\
\hline 2. & gyya (mother) & мама (mother) \\
3. & apa (father) & пеловек (person) \\
4. & játék (toy/game) & дом (father) \\
5. & barát (friend) & игрушка (toy) \\
6. & család (family) & ребенок (child) \\
7. & ház (house) & семья (family) \\
8. & anyuka (mom) & друг (friend) \\
9. & ruha (clothes) & вода (water) \\
10. & víz (water) & цвет (colour) \\
\hline
\end{tabular}

\begin{tabular}{c||ll||}
\hline & \multicolumn{1}{|c|}{ Hungarian } & \multicolumn{1}{c|}{ Russian } \\
\hline 1. & ember (man/person) & время (time) \\
2. & év (year) & года (year) \\
3. & nap (day) & работы (work) \\
4. & Szó (word) & России (Russia) \\
5. & világ (world) & компании (company) \\
6. & Isten (God) & день (day) \\
7. & rendszer (system) & случае (case) \\
8. & pont (point) & области (region) \\
9. & dolog (thing) & жизни (life) \\
10. & város (town) & человек (person) \\
\hline
\end{tabular}

\subsection{Verbs}

In order to more properly depict the linguistic consciousness of the two investigated groups, modal verbs and substantive verbs were omitted from the top 10 results of both the research results and the Araneum frequency list (Table 3.).

Table 3. Most Frequent verbs from Own Research and from Araneum Corpora*

\begin{tabular}{|c|c|c|c|c|c|}
\hline & \multicolumn{2}{|c|}{ Verbs from own research } & & \multicolumn{2}{|c|}{ Verbs from Araneum corpora } \\
\hline & Hungarian & Russian & & Hungarian & Russian \\
\hline 1. & játszik (play) & знать (know) & 1. & tud (know) & является (seems) \\
\hline 2. & tud (know) & играть (play) & 2. & mond (said) & позволяет (allow) \\
\hline 3. & szeret (like/love) & жить (live) & 3. & áll (stand) & следует (follow) \\
\hline 4. & lakik (live) & любить (like/love) & 4. & kerül (cost) & делать (do) \\
\hline 5. & válaszol (reply) & пить (drink) & 5. & sikerül (succeed) & получить (receive) \\
\hline 6. & felnő (grow up) & делать (do) & 6. & jelent (mean) & имеют (have) \\
\hline 7. & mond (say) & дружить (be friends) & 7. & történik (happen) & купить (buy) \\
\hline 8. & csinál (do) & помогать (help) & 8. & kap (receive) & сказать (say) \\
\hline 9. & megy (go) & летать (fly) & 9. & készïl (nrenar & происходит \\
\hline 10. & beszél (speak) & говорить (speak) & & & (happen) \\
\hline 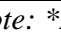 & al ver & & 10. & tesz (put) & находится (located) \\
\hline
\end{tabular}

The core verbs as lexical elements of Hungarian and Russian preschoolers' linguistic consciousness include play, like/love, know, do, and live, as well as verbs connected to speaking (reply, say, speak). Like/love and play are clearly over-represented in the preschoolers' responses when compared to the Araneum database. A culture- and language-bound item in the Russian results is дружить (be friends), widespreadly used by Russian children.

\subsection{Key Single-Words}

Key single-words were identified using the Sketch Engine corpus linguistic tool. Key single-words are defined as one-word units (individual words) that appear more frequently in the focus corpus than in the reference corpus. These lexical items well depict the peculiarities of preschoolers' linguistic consciousness in the Russian and Hungarian context (Table 4.). 
Table 4. Most Frequent Key Single-Words in Preschoolers’ Associations

\begin{tabular}{c||lc||lc||}
\hline & \multicolumn{1}{c||}{ Hungarian } & \multicolumn{1}{c||}{ Russian } \\
\hline \multicolumn{1}{l||}{ Association } & Freq. & \multicolumn{1}{c}{ Association } & Freq. \\
\hline 1. & legózik (play lego) & 13 & братик (bro) & 31 \\
2. & babakonyha (dollhouse) & 11 & лего (lego) & 15 \\
3. & lego (lego) & 8 & прятки (hide and seek) & 7 \\
4. & bújócska (hide and seek) & 9 & догонялки (play tag) & 5 \\
5. & babázik (play with dolls) & 10 & ребёнок (child) & 49 \\
6. & szarv (horn) & 28 & дружить (be friends) & 5 \\
7. & Jézuska (little Jesus) & 14 & сестрёнка (little sister) & 4 \\
8. & társasozik (play board game) & 6 & домик (small house) & 10 \\
9. & plüss (plush) & 12 & крылышко (little wing) & 3 \\
10. & bújócskázik (play hide and seek) & 6 & крыльев (wings) & \\
\hline
\end{tabular}

Note: *Proper names and double occurrences are excluded

Lego proves to be a key lexical element in the case of both Russian and Hungarian children, appearing in number 1 (play lego) and 3 (lego) position in the Hungarian and in the second place in the Russian results (lego). Children predominantly associate to either toys surrounding them (lego, dollhouse, plush), or games they play (hide and seek, tag, board game, playing with dolls).

Counter to Hungarian children, Russians mention friends and family members more typically, including bro, little sister and child - this is not apparent in the Hungarian sample.

References to religion can be grasped in the Hungarian associations including Jézuska (little Jesus). Russian children meanwhile mention wings and little wings (крыльишко) in the context of their attempt to describe an angel.

\section{Summary}

A multidisciplinary perspective merging pedagogical, linguistic and psychological aspects in investigating Russian and Hungarian children's linguistic consciousness yielded in valuable results. An association experiment was conducted with 100-100 preschoolers in Russia and Hungary, applying the shoulder-to-shoulder method. The outcome revealed universalistic features of 4-5-year-old children's linguistic consciousness including the perception of the family or of a friend.

Children characterize themselves as well as their friends as small, kind, good, nice persons predominantly with positive features.

Language- and culture-bound dissimilarities were revealed including religious references (little Jesus) and unique lexicon of specific etymology (дружить: be friends; маленький-мальи: small-kiddy).

Effects of globalization were pinpointed through the identification of brand names (lego, Duplo, Trudi), cartoons, and info-communication tools (mobile phones, tablets, computers). The research results suggest that lego plays a notable role in the linguistic consciousness of both Hungarian and Russian pre-school children.

Generally, the investigation based on the association experiment, complemented by the shoulder-to-shoulder method proved to be an appropriate and effective tool in mapping and cross-culturally comparing Hungarian and Russian preschoolers' linguistic consciousness. The research will hopefully be extended to further countries in the near future.

\section{Acknowledgement}

This research was financially supported by the Russian Foundation for Basic Research (project \#18-512-23004) and the New National Excellence Program (UNKP-17-4) of the Ministry of Human 
Capacities of Hungary.

\section{References}

[1] N.V. Ufimtseva, The Associative Dictionary as a Model of the Linguistic Picture of the World, Procedia - Social and Behavioral Sciences, Elsevier, Tomsk, 2014, 154:36-43.

[2] Y.F. Tarasov, Jazikovoje soznanije - perespektivi issledovanija [Language consciousness research perspectives], Etnokulturnaja spetsifika yazykovogo soznaniya [The ethnocultural specificity of language consciousness], Moscow: Institut Jazikoznania RAN, 1996, 7-22.

[3] V. Benko, Aranea: Yet Another Family of (Comparable) Web Corpora, In: P. Sojka, A. Horák, I. Kopeček, and K. Pala (eds.): Text, Speech and Dialogue, 17th International Conference, TSD 2014, Brno, Czech Republic, September 8-12, 2014. Proceedings. LNCS 8655. Springer International Publishing Switzerland, 2014., 257-264.

[4] A. Kilgarriff, V. Baisa, J. Bušta, M- Jakubíček, V. Kovář, J. Michelfeit, P. Rychlý, and V. Suchomel, The Sketch Engine: ten years on. Lexicography, 2014, 1: 7-36.

[5] M. Griffin, M. Lahman, and M. Opitz, Shoulder-to-shoulder research with children: Methodological and ethical considerations, Journal of Early Childhood Research 2016, Vol. 14(1) 18-27.

[6] H. Hendrick, The child as a social actor in historical sources in Christiansen, Pia and James, A. (eds.) Researck with children, London, Falmer Press, 2000 